\title{
Treatment with Rhus tripartita extract curtails isoproterenol-elicited cardiotoxicity and oxidative stress in rats
}

\author{
Abdelaaty A. Shahat ${ }^{1,2^{*}}$, Mansour S. Alsaid', Syed Rafatullah', Mohammed O. Al-Sohaibani ${ }^{3}$, Mohammad K. Parvez $^{1}$,
} Mohammed S. Al-Dosari ${ }^{1}$, Vassiliki Exarchou ${ }^{4}$ and Luc Pieters ${ }^{4}$

\begin{abstract}
Background: Consumption of plant-derived nutraceuticals and crude drugs in traditional medicine is widely believed to confer beneficial effects in thwarting the progression of cardiovascular diseases. Rhus tripartita (family Anacardiaceae) has been traditionally used to treat a wide range of ailments.
\end{abstract}

Methods: In the present study we investigated the protective effects of an alcoholic extract of the stem part of Rhus tripartita male genotype (RTSM) on experimentally induced myocardial injury in rats. To this end, cardiac injury was induced by administration of isoproterenol (ISO) and serum enzyme markers, lipid profiles and cardiac tissue redox status were determined following RTSM treatment (250 and $500 \mathrm{mg} / \mathrm{kg}$ ).

Results: As a result, RTSM treatment significantly mitigated ISO-triggered upregulation of cardiac-specific markers of injury creatine kinase and lactate dehydrogenase. RTSM treatment significantly attenuated ISO-induced increase in serum cholesterol and triglycerides as well alterations in serum lipoproteins. Determination of oxidative balance showed that RTSM treatment significantly blunted ISO-induced increase in malondialdehyde and decrease in nonprotein sulfhydryl in cardiac tissue. Six compounds were isolated and identified as gallocatechin 1, taxifolin 2, myricetin-3-O- $\beta$-glucoside 3, catechin 4, epicatechin 5, and 3',8-binaringenin 6. Compound 6 was isolated for the first time from the stem part of Rhus tripartita. Furthermore, RTSM treatment enhanced the survival fraction of cardiac cells exposed to oxidative stress in vitro.

Conclusion: We conclude that the antioxidant properties of RTSM treatment underpin its cardioprotective pharmacological effects, thus, providing biological evidence for the treatment of cardiovascular diseases using Rhus tripartita in indigenous medicine.

Keywords: Rhus tripartita, Anacardiaceae, Cardiovascular diseases, Isoproterenol, Oxidative stress, Chemical components

Abbreviations: NP-SH, Nnonprotein Sulfhydryl; LPO, Lipid Peroxidation; TC, Total Cholesterol; TG, Ttriglycerides; HDL-C, High-Density Lipoproteins; MI, Myocardial infarction; CVD, Cardiovascular disease; DMEM, Dulbecco's Modified Eagle's medium; DCFH, 2,7-Dichlorodihydrofluorescein diacetate; OD, Optical Density; TCA, Trichloroacetic acid; EDTA, Ethylene diaminetetraacetic acid; DTNB, 5,5'-dithio-bis(2-nitrobenzoic acid); VLDL, Very-low-density lipoprotein; LDL, Low Density Lipoprotein Cholesterol

\footnotetext{
* Correspondence: aashahat@hotmail.com

${ }^{1}$ Pharmacognosy Department (Medicinal Aromatic \& Poisonous Plants

Research (entre), College of Pharmacy, King Saud University, P.O. Box 2457,

Riyadh 11451, Saudi Arabia

${ }^{2}$ Phytochemistry Department, National Research Centre, 33 El Bohouth St.

(former El Tahrir st.) 12622, Dokki, Giza, Egypt

Full list of author information is available at the end of the article
}

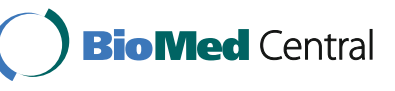

(C) 2016 The Author(s). Open Access This article is distributed under the terms of the Creative Commons Attribution 4.0 International License (http://creativecommons.org/licenses/by/4.0/), which permits unrestricted use, distribution, and reproduction in any medium, provided you give appropriate credit to the original author(s) and the source, provide a link to the Creative Commons license, and indicate if changes were made. The Creative Commons Public Domain Dedication waiver (http://creativecommons.org/publicdomain/zero/1.0/) applies to the data made available in this article, unless otherwise stated. 


\section{Background}

Cardiovascular disease (CVD) is a major cause of morbidity and mortality in the modern era and includes conditions such as myocardial infarction, angina pectoris, and atherosclerosis [1]. Although several mechanisms are speculated to participate in the pathogenesis of myocardial insufficiency, the putative roles of these processes remain elusive. Mounting evidence suggests that deranged myocardial redox balance, enhanced inflammation and reduced cell survival influence normal heart function in CVD [2]. Herbal remedies have been utilized for various diseases including heart diseases [3, 4], as these herbs constitute a rich source of bioactive phytochemicals such as flavonoids, polyphenols and other constituents which have been shown to possess beneficial effects in CVD $[5,6]$. The Anacardiaceae family of plants consists of trees, shrubs and/or woody vines belonging mainly to the genus Rhus, with about 250 species which occurs mostly in the tropics and subtropics and various temperate zones of the world [7, 8]. A number of Rhus species are used in folkloric and traditional medicine of many countries including Saudi Arabia. Rhus tripartita (Ucria) Grande is found wildly in the North-Eastern part of Saudi Arabia. In Arabian traditional medicine, different parts of Rhus tripartita plant have been used for centuries to treat inflammatory conditions as well as gastrointestinal and cardiovascular disorders [9]. The fruits of this plant are consumed freshly and in decoction to treat diarrhea and ulcers [10]. Previously, extracts and pure isolates of Rhus tripartita were isolated and shown to possess robust anti-inflammatory and antioxidant properties [11]. Rhus species were documented to possess a wide array of pharmacological activities such as antiinflammatory, antinephritic, antimicrobial [12], antioxidant and breast cancer preventive properties [13, 14]. Rhus coriara (Sumac) was reported to be used for the prevention and treatment of atherosclerosis [15]. Recently, an attempt has been made to intensify the solvent extraction of total phenols and tannins from the bark of Rhus tripartita. From the same species of Rhus, flavonoids and isoflavonoids have been isolated from its aerial parts and characterized. Furthermore, butein (a polyphenolic component) was extracted from another species, Rhus verniciflua.

In our previous study on crateagus species, the phytochemical constituents (flavonoids and proanthocyanidins) and the therapeutic nature such as cardiovascular effects and antioxidant activity were conducted [16-18]. Our current research on Saudi Arabian Rhus tripartita showed that it is rich in flavonoids and proanthocyanidins compounds.

On account of its wide use in Arabian traditional medicine for the prevention of CVD, the present study, thus, explored the possible protective effect of an alcoholic extract of the stem part of Rhus tripartita male genotype (RTSM) against isoproterenol (ISO)-induced cardiac injury in rats.

\section{Methods}

\section{Plant material}

Fresh sample of stem bark of Rhus tripartita was collected in April 2013 at Hail area in the northwestern part of Saudi Arabia. The plants were identified by an expert Taxonomist at the Herbarium Unit. The voucher specimens have been deposited (SY 202/2013) at the Herbarium of the Faculty of Pharmacy, King Saud University, Riyadh, Saudi Arabia.

\section{Extraction and isolation}

The stem of the plant was collected and air-dried at room temperature. The dried sample was powdered; $1100 \mathrm{~g}$ of dried sample was extracted with $4000 \mathrm{ml}$ of $80 \%$ aqueous methanol three times. The extracts were filtrated through Whatmann No. 1 and combined followed by concentration using a rotary evaporator under reduced pressure at $40{ }^{\circ} \mathrm{C}$ to yield a dry extract of $231 \mathrm{~g}(21 \%)$. The percentage yield was expressed in terms of air dried weight of plant materials.

The dry extract $(100 \mathrm{~g})$ was diffused in $400 \mathrm{ml}$ of distilled water and extracted successively with dichloromethane $\left(\mathrm{CH}_{2} \mathrm{Cl}_{2}\right)$, ethyl acetate (EtOAc) and n-butanol $(\mathrm{n}-\mathrm{BuOH})(3 \times 300 \mathrm{ml})$ respectively. Each extract was dried over anhydrous sodium sulfate. The organic fractions were concentrated under reduced pressure at temperature not exceeding $35{ }^{\circ} \mathrm{C}$ and the residual aqueous layer was lyophilized named (RTSM1), (RTSM2) (RTSM3) and (RTSM4) respectively. The EtOAc fraction (RTSM2) (20 g) was subjected to a Sephadex LH-20 column (Pharmacia) (90 x $4 \mathrm{~cm}$ ), EtOH was used as a mobile phase. The fractions $50 \mathrm{ml}$ each are collected and examined on TLC (Silica gel 60 F254, layer thickness $0.2 \mathrm{~mm}$, Merck), the upper layer of mixture of EtOAc-HOAc-HCOOH- $\mathrm{H}_{2} \mathrm{O}(30 / 0.8 / 1.2 / 8)$ was used as a mobile phase. The TLC were viewed under UV (254 and $366 \mathrm{~nm}$ ) before and after spraying with Neu's spray reagent (reagent a) and vanillin $\mathrm{H}_{2} \mathrm{SO}_{4}$ (reagent b). Fractions 16-20, 21-35, 36-45, 46-60, 61-74 and 75-86 were combined together in one group and named as (RTSM2-I), (RTSM2-II), (RTSM2-III) and (RTSM2-IV) and (RTSM2-V) respectively.

The sub-fractions RTM2-II was subjected to Sephadex LH-20 column chromatography using methanol as eluent to give compounds $\mathbf{1}$ and 2. Subfraction RTM2III was subjected to Sephadex LH-20 using methanol as mobile phase to give compounds $3, \mathbf{4}$ and 5 . The sub fraction RTSM2-IV was subjected to column chromatography C18-reversed-phase with $\mathrm{MeOH}-\mathrm{H}_{2} \mathrm{O}$ (6:4) as eluent to give compound $\mathbf{6}$.

\section{NMR spectroscopy}

NMR spectra were recorded in deuterated methanol $\left(\mathrm{CD}_{3} \mathrm{OD}\right)$ on a Bruker DRX-400 spectrometer (Bruker 
Biospin GmbH, Rheinstetten, Germany) operating at 400.13 $\mathrm{MHz}$ for ${ }^{1} \mathrm{H}$ and at $100.61 \mathrm{MHz}$ for ${ }^{13} \mathrm{C}$.

\section{In vitro cardioprotective assay}

The H9C2 cells (human cardiomyoblast) were grown in DMEM medium, supplemented with $10 \%$ heatinactivated bovine serum (Gibco) and $1 \mathrm{x}$ penicillinstreptomycin (Gibco) at $37{ }^{\circ} \mathrm{C}$ with $5 \% \mathrm{CO}_{2}$ supply. The cells were seeded $\left(0.5 \times 10^{5}\right.$ cells/well, in triplicate $)$ in a 96-well flat-bottom plate (Becton-Dickinson Labware) and grown over night. Cardioprotective activity of RTSM was determined against 2, 7-dichlorofluorescein (DCFH; Sigma) cytotoxicity $\left(\mathrm{IC}_{50}: 125 \mu \mathrm{g} / \mathrm{ml}\right)$, using MTT assay (MTT-Cell proliferation Assay Kit, Tervigen) as described previously [19] (Al-Yahya et al., 2016). Four doses of $\operatorname{RTSM}(31.25,62.5,125$, and $250 \mu \mathrm{g} / \mathrm{ml})$ were prepared in DMSO followed by dilutions in DMEM media. (>0.1 \%, final). The cells were replenished with fresh media containing $120 \mu \mathrm{g} / \mathrm{ml}$ DCFH plus a dose of RTSM, including DCFH only-treated control. The cells were incubated for $48 \mathrm{~h}$ followed by MTT assay as per the manufacturer's instruction. The optical density (OD) was recorded at $570 \mathrm{~nm}$ in a microplate reader (BioTek, ELx800). The cell survival fraction was determined by the non-linear regression analysis by Excel software, using the following equation:

$$
\text { Survival fraction }=\frac{O D[\mathrm{~s}]-O D[b]}{O D[c]-O D[b]}
$$

Where $\mathrm{OD}[\mathrm{s}], \mathrm{OD}[\mathrm{b}]$ and $\mathrm{OD}[\mathrm{c}]$ are the absorbance of sample, blank and negative control, respectively.

Also, a direct visual investigation was made under an inverted microscope (Optica, 40x and 100x) to observe any morphological changes in the cells cultured with different concentrations of RTSM and/or DCFH at 24 and $48 \mathrm{~h}$.

\section{In vivo cardioprotective potential assay Animals}

The present study was approved by the Research Ethics Committee of the College of Pharmacy, King Saud University (Riyadh, Saudi Arabia). The handling of animals was in compliance with the Guidelines for the Care and Use of Laboratory Animals by the Animal Care Center. Wistar albino male rats, $180 \pm 20$ g were obtained from the Experimental Animal care Center of the college of Pharmacy, King Saud University, Riyadh. The animals were caged individually in hygienic conditions and kept in a controlled environment with a $12 \mathrm{~h}$ lightdark cycle at $22 \pm 3{ }^{\circ} \mathrm{C}$ for a week before the experiment. The animals were offered free access to purina chow diet and water ad libitum.

\section{In vivo cardioprotective assay}

Myocardial infarction (MI) induction in rats isoproterenol (ISO) (a synthetic catecholamine), is a wellaccepted noninvasive drug to induce MI in rat model [20]. The physiopathological and morphological changes of ISO-induced myocardial necrosis are similar to those observed in humans [21]. ISO was dissolved in normal saline and injected subcutaneously ( $85 \mathrm{mg} / \mathrm{kg}$ b.w.) for two consecutive days at the interval of $24 \mathrm{~h}$ [20].

The animals were randomly divided into four groups, each containing six rats. Group I (normal group; control) animals received normal saline using intragastric tube for 14 days, and saline was administered $(500 \mu \mathrm{l} /$ rat, s.c.) on day 13 and 14 (24 h interval). Group II (ISO control; ISO) animals received normal saline for 14 days, and received ISO (85 mg/kg, s.c.) on day 20 and 21 (24 h interval). Group III (RTSM + ISO) animals received RTSM ( $250 \mathrm{mg} / \mathrm{kg} /$ day) orally for 21 days along with concurrent administration of ISO $(85 \mathrm{mg} / \mathrm{kg}$, s.c. at $24 \mathrm{~h}$ interval) on day 20 and 21. Group IV (RTSM + ISO) animals received RTSM (500 $\mathrm{mg} / \mathrm{kg} /$ day) and ISO (85 mg/kg, s.c. at $24 \mathrm{~h}$ interval) on day 20 and 21 .

\section{Estimation of marker enzymes}

Levels of plasma alanine aminotransferase (ALT), aspartate aminotransferase (AST) [22], lactate dehydrogenase (LDH) [23], and creatine kinase (CK) [24] were then estimated usingReflotron ${ }^{\odot}$ Plus Analyzer and Roche Diagnostic Kits (Roche Diagnostics GmbH, Mannheim, Germany).

\section{Estimation of lipid profile}

The total cholesterol (TC) [25], triglycerides (TG) [26], and high-density lipoproteins (HDL-C) [27] were estimated in plasma using the Refloton instrument of the specific kits (Roche Diagnostics GmbH, Mannheim, Germany).

\section{Lipid Peroxidation (LPO) determination}

The method reported by Utley et al. [28] was followed. The heart tissue was homogenized in $0.15 \mathrm{M} \mathrm{KCl}$ (at $4^{\circ}$ $\mathrm{C}$, Potter-Elvehjem type $\mathrm{C}$ homogenizer) to give a $10 \% \mathrm{w} / \mathrm{v}$ homogenate. Aliquots of homogenate $(1 \mathrm{~mL})$ were incubated at $37{ }^{\circ} \mathrm{C}$ for $3 \mathrm{~h}$ in a metabolic shaker. Following this, $1 \mathrm{~mL}$ of $10 \%$ aqueous trichloroacetic acid (TCA) was added and mixed. The mixture was then centrifuged at $800 \mathrm{~g}$ for $10 \mathrm{~min}$. Following this, supernatant $(1 \mathrm{~mL})$ was mixed with $1 \mathrm{~mL}$ of $0.67 \%$ thiobarbituric acid and placed in a boiling water bath for $10 \mathrm{~min}$. The mixture was cooled and diluted with $1 \mathrm{~mL}$ distilled water. The absorbance of the solution was then read using spectrophotometer(UVmini-1240, Shimadzu Italia, Milano, Italy) at $532 \mathrm{~nm}$. The content of malondialdehyde 
(MDA) (nmol/g wet tissue) was then calculated, by reference to a standard curve of MDA solution.

\section{Estimation of Non-Protein Sulfhydryl Groups (NP-SH)}

Cardiac NP-SH was measured according to the method of Sedlak and Lindsay [29]. The heart was homogenized in ice-cold $0.02 \mathrm{M}$ ethylene diaminetetraacetic acid (EDTA). Aliquots of $5 \mathrm{~mL}$ of the homogenates were mixed in $15 \mathrm{~mL}$ test tubes with $4 \mathrm{~mL}$ of distilled water and $1 \mathrm{~mL}$ of $50 \%$ TCA. The tubes were shaken intermittently for $10 \mathrm{~min}$ and centrifuged at $3000 \mathrm{rpm}$. Two milliliters of supernatant were mixed with $4 \mathrm{~mL}$ Tris buffer $(0.4 \mathrm{~mol} / \mathrm{L}, \mathrm{pH} 8.9)$ and $0.1 \mathrm{~mL}$ of $5,5^{\prime}$-dithiobis(2-nitrobenzoic acid) (DTNB) and the sample was shaken. The absorbance was read within $5 \mathrm{~min}$ of addition of DTNB at $412 \mathrm{~nm}$ against a reagent blank.

\section{Determination of Total Protein (TP)}

The TP was estimated by the kit method, supplied by Crescent Diagnostics, Jeddah, Saudi Arabia. The absorbance of this complex at $546 \mathrm{~nm}$ is proportional to the protein concentration. The serum total protein was calculated using the equation: Serum total protein $=$ Abs. sample/Abs. standard $\times$ concentration of standard (1).

\section{Histopathological studies}

The heart tissues were fixed in $10 \%$ buffered formalin and processed using a VIP tissue processor. The processed tissues were then embedded in paraffin blocks and sections of about $5 \mu \mathrm{m}$ thickness were cut by employing an American optical rotary microtome. These sections were stained with hematoxylin and eosin using routine procedures [30]. The slides were examined for "pathomorphological changes.

\section{Results}

3',8 Binaringenin (6)

NMR data:

${ }^{1} \mathrm{H}$ NMR $\left(\mathrm{CD}_{3} \mathrm{OD}\right): \delta 7.23(1 \mathrm{H}, \mathrm{s}, \mathrm{H}-2$ '), 7.17 (3H, d, J $=8.1 \mathrm{~Hz}, \mathrm{H}-2$ "', H-6, H-6"'), $6.88(1 \mathrm{H}, \mathrm{d}, \mathrm{J}=8.4 \mathrm{~Hz}$, H-5'), 6.71 (3H, d, J = 8.1 Hz, H-3"', H-5"'), $6.05(1 \mathrm{H})$, br s) and $5.89(2 \mathrm{H}$, br s, H-6,H-6", H-8), $5.34(1 \mathrm{H}, \mathrm{m})$ and $5.23(1 \mathrm{H}, \mathrm{m})\left(\mathrm{H}-2, \mathrm{H}-2\right.$ "), $3.02\left(2 \mathrm{H}, \mathrm{m}, \mathrm{H}-3 \mathrm{ax}, \mathrm{H}-3{ }^{\prime \prime}{ }_{\mathrm{ax}}\right)$, $2.79(1 \mathrm{H}, \mathrm{m})$ and $2.56(1 \mathrm{H}, \mathrm{m})\left(\mathrm{H}-3_{\mathrm{eq}}, \mathrm{H}-3^{\prime \prime}{ }_{\mathrm{eq}}\right)$.

${ }^{13} \mathrm{C}$ NMR (CD $\left.{ }_{3} \mathrm{OD}\right): \delta \quad 197.0$ and $195.5 \quad(\mathrm{C}-4$, C-4")166.9 and 164,7 (C-7, C-7")164.0 (C-5), 163.5 (C-4"'), 163.2 (C-5"), 160.6 (C-4'), 157.2 (C-9), 155.2 (C-9"), 131.2 (C-6'), 129.8 (C-1'), 129.2 (C-1"'), 127.3 (C-2"', C-6"'), 126.4 (C-2'), 120.0 (C-3'), 115.2 (C-3"', C-5"'), 114.8 (C-5), 105.6 (C-!"), 102.0 (C-10, C-10"), 95.6 and 95.0 (C-6, C-6"), 94.8 (C-8), 79.2 (C-2), 78.5 (C-2"); 42.6 and 42.2 (C-3 and C-3").<smiles>O=C1CC(c2ccc(O)c(-c3c(O)cc(O)c4c3OC(c3ccc(O)cc3)CC4=O)c2)Oc2cc(O)cc(O)c21</smiles>

\section{Compound 6}

\section{In vitro cardioprotective potential of RTSM}

The cardioprotective activity of RTSM against DCFHinduced injury on cultured $\mathrm{C} 9 \mathrm{H} 2$ cells was investigated. While DCFH-toxicated cardiomyocytes were recovered to $\sim 10 \%$ with $62.5 \mu \mathrm{g} / \mathrm{ml}$ dose of RTSM, supplementation with 125 and $250 \mu \mathrm{g} / \mathrm{ml}$ of RTSM further enhanced the cardiomyocytes proliferation by $\sim 15$ and $30 \%$, respectively. Therefore, RTSM at the best minimal dose of $250 \mu \mathrm{g} / \mathrm{ml}$ showed the protective activity on cultured cardiomyocytes.

\section{In vivo cardioprotective potential of RTSM}

To investigate the cardiovascular modulatory effects of RTSM treatment, we used the ISO-induced myocardial injury model in rats [31-33]. Firstly, we examined the effect of RTSM on ISO-induced changes in serum markers. To this end, administration of ISO $(85 \mathrm{mg} / \mathrm{kg})$ significantly increased serum levels of the enzymes SGOT, SGPT, GST and ALP, an effect significantly and dose-dependently thwarted by pretreatment with 250 and $500 \mathrm{mg} / \mathrm{kg}$ RTSM (Table 1). ISO administration further enhanced LDH and CK, cardio-specific serum markers of injury (Table 1). As shown in Table 1, pretreatment of rats with RTSM significantly attenuated ISO-elicited increase in serum LDH and CK suggesting the cardioprotective effects of RTSM treatment.

Experimental cardiac injury triggered by ISO is further associated with an alteration of serum lipid profiles [34]. To this end, determination of serum lipids revealed that administration of ISO significantly enhanced the serum levels of cholesterol, triglycerides, VLDL and LDL while significantly lowering serum HDL level (Table 2). As shown in Table 2, treatment of rats with RTSM significantly and dose-dependently counteracted ISO-induced alterations in serum lipids indicating a vascular protective role of RTSM treatment. 
Table 1 Effect of RTSM on serum marker enzymes of control and experimental rats

\begin{tabular}{|c|c|c|c|c|c|c|c|c|c|c|c|c|c|}
\hline \multirow[t]{2}{*}{ Treatments } & \multirow{2}{*}{$\begin{array}{l}\text { Dose } \\
\mathrm{mg} / \mathrm{kg}\end{array}$} & \multicolumn{2}{|l|}{$\mathrm{SGOT}(\mathrm{U} / \mathrm{L})$} & \multicolumn{2}{|l|}{ SGPT(U/L) } & \multicolumn{2}{|l|}{ GGT(U/L) } & \multicolumn{2}{|l|}{$\mathrm{ALP}(\mathrm{U} / \mathrm{L})$} & \multicolumn{2}{|l|}{$\mathrm{LDH}(\mathrm{U} / \mathrm{L})$} & \multicolumn{2}{|l|}{$\mathrm{CK}(\mathrm{U} / \mathrm{l})$} \\
\hline & & Mean \pm SE & $\%$ change & Mean \pm SE & $\%$ change & Mean \pm SE & $\%$ change & Mean \pm SE & $\%$ change & Mean \pm SE & $\%$ change & Mean \pm SE & $\%$ change \\
\hline Control & & $79.00 \pm 3.31$ & & $30.01 \pm 2.44$ & & $4.85 \pm 0.23$ & & $217.16 \pm 11.14$ & & $106.08 \pm 6.45$ & & $135.16 \pm 5.43$ & \\
\hline ISO only & 85 & $200.00 \pm 5.78^{* * * a}$ & & $181.00 \pm 7.33^{* * * a}$ & & $13.65 \pm 0.33^{* * * a}$ & & $435.30 \pm 10.02^{* * * a}$ & & $165.66 \pm 6.72^{* * a}$ & & $227.33 \pm 10.18^{* * * a}$ & \\
\hline RTSM+ ISO & 250 & $159.00 \pm 6.53^{* * * b}$ & $21 \downarrow$ & $150.83 \pm 4.11^{* * \mathrm{~b}}$ & $17 \downarrow$ & $10.55 \pm 0.40^{* * * b}$ & $23 \downarrow$ & $379.33 \pm 13.32^{* b}$ & $3 \downarrow$ & $150.00 \pm 4.91^{b}$ & $9 \downarrow$ & $201.50 \pm 5.51^{b}$ & $11 \downarrow$ \\
\hline RTSM+ ISO & 500 & $154.00 \pm 4.01 * * * b$ & $23 \downarrow$ & $140.00 \pm 5.57^{* * b}$ & $23 \downarrow$ & $9.16 \pm 0.25^{* * * b}$ & $33 \downarrow$ & $350.33 \pm 11.42^{* * * b}$ & $20 \downarrow$ & $139.66 \pm 6.19^{* b}$ & $9 \downarrow$ & $185.50 \pm 7.34^{* b}$ & $18 \downarrow$ \\
\hline
\end{tabular}

All values represent mean \pm SEM. ${ }^{*} p<0.05,{ }^{* *} p<0.01,{ }^{* * *} p<0.001$; ANOVA, followed by Dunnett's multiple comparison test

aAs compared with normal group

${ }^{\mathrm{b}}$ As compared with only ISO only group 
Table 2 Effect of RTSM on serum lipid metabolism and serum lipoproteins of control and experimental rats

\begin{tabular}{|c|c|c|c|c|c|c|c|c|c|c|c|}
\hline \multirow[t]{2}{*}{ Treatments } & \multirow{2}{*}{$\begin{array}{l}\text { Dose } \\
\mathrm{mg} / \mathrm{kg}\end{array}$} & \multicolumn{2}{|l|}{ Cholesterol(mg/dl) } & \multicolumn{2}{|c|}{ Triglycerides(mg/dl) } & \multicolumn{2}{|l|}{$\mathrm{HDL}-\mathrm{C}(\mathrm{mg} / \mathrm{dl})$} & \multicolumn{2}{|l|}{ VLDL-C(mg/dl) } & \multicolumn{2}{|l|}{ LDL-C(mg/dl) } \\
\hline & & $\overline{M e a n} \pm$ SE & $\%$ change & $\overline{M e a n} \pm$ SE & $\%$ change & $\overline{M e a n} \pm$ SE & $\overline{\% c h a n g e}$ & $\overline{M e a n} \pm$ SE & $\%$ change & $\overline{M e a n} \pm$ SE & $\%$ change \\
\hline$\overline{\text { Control }}$ & & $98.1 \pm 5.15$ & & $54.56 \pm 3.45$ & & $42.66 \pm 1.17$ & & $10.91 \pm 0.69$ & & $44.52 \pm 5.57$ & \\
\hline ISO only & 85 & $199.83 \pm 7.21^{* * * a}$ & & $155.00 \pm 8.00^{* * * a}$ & & $24.66 \pm 1.56^{* * * a}$ & & $31.001 .60^{* * * a}$ & & $144.16 \pm 6.03^{* * * a}$ & \\
\hline RTSM+ ISO & 250 & $179.83 \pm 4.33^{* b}$ & $10 \downarrow$ & $120.33 \pm 3.44^{* * \mathrm{~b}}$ & $22 \downarrow$ & $27.66 \pm 0.76$ & $12 \uparrow$ & $24.06 \pm 0.68^{* * b}$ & $23 \downarrow$ & $128.10 \pm 4.83^{b}$ & $11 \downarrow$ \\
\hline RTSM+ ISO & 500 & $157.83 \pm 5.83^{* *}$ & $21 \downarrow$ & $105.61 \pm 1.96^{* * * \mathrm{~b}}$ & $32 \downarrow$ & $32.50 \pm 1.17^{* * \mathrm{~b}}$ & $32 \uparrow$ & $21.12 \pm 0.39 * * * b$ & $31 \downarrow$ & $104.21 \pm 6.57^{* * \mathrm{~b}}$ & $28 \downarrow$ \\
\hline
\end{tabular}

All values represent mean \pm SEM. ${ }^{*} p<0.05$

${ }^{* *} p<0.01, * * * p<0.001 ;$ ANOVA, followed by Dunnett's multiple comparison test

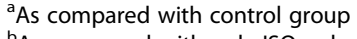

${ }^{\mathrm{b}}$ As compared with only ISO only group 


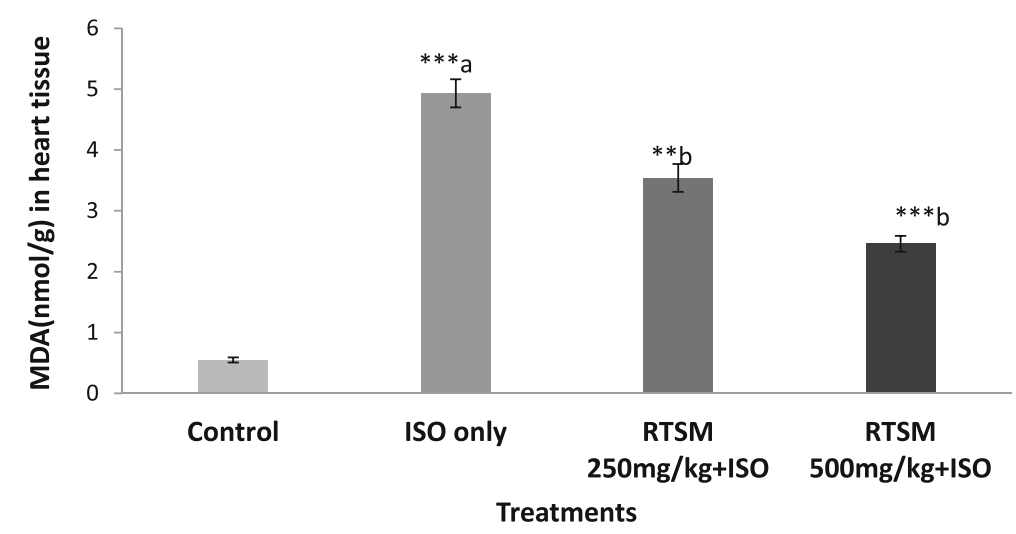

Fig. 1 Effect of RTSM on the level of MDA in the heart tissue of the rats treated with Isoproteronol. All value represent mean $\pm S E S M * * P<0.01$,

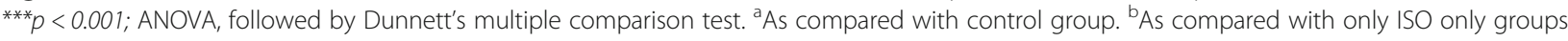

A further series of experiments addressed the possible role of redox sensitivity of RTSM treatment in ameliorating ISO-induced cardiotoxicity. To this end, we determined malondialdehyde (MDA) levels in cardiac tissue isolated from rats administered with ISO. As a result, ISO administration significantly upregulated tissue MDA levels, an effect that was significantly and dose-dependently mitigated by pretreatment with RTSM (Fig. 1).

Additional experiments were performed to further elucidate the pivotal role of RTSM treatment in modulating the redox imbalance induced by ISO. ISO treatment is associated with decreased nonprotein sulfhydryl (NP$\mathrm{SH})$ levels in cardiac tissue $[35,36]$. As illustrated in Fig. 2, administration of ISO significantly reduced NP$\mathrm{SH}$ levels in cardiac tissue, an effect that was significantly and dose dependently blunted by pretreatment with RTSM indicating that the antioxidant effects of RTSM treatment are a critical mechanism in its cardio protective effect. Further examination of total protein levels in cardiac tissue revealed that ISO significantly decreased total protein levels, an effect that was significantly and dose-dependently counteracted by RTSM treatment (Fig. 3).
DCFH is generally used to measure in vitro oxidative stress generated by free-radicals through oxidation of DCFH to the fluorescent DCF [37].

To confirm the antioxidant effects of RTSM treatment in conferring a protective response against ISO-induced cardiac injury, we analyzed the survival fraction of cardiomyocytes ex vivo against DCFH -toxicity. As a result, survival fraction of cardiomyocytes treated with RTSM $(125 \mu \mathrm{g} / \mathrm{ml})$ was significantly enhanced by attenuating DCFH effect (Fig. 4).

\section{Histological improvement of injured myocardiac tissues by RTSM}

The histology of rat cardiac tissues showed that ISOelicited inflammatory lesions led to structure disorders of muscle fibers as well as infiltration of acute inflammatory cells, including extravasation of red blood cells (Fig. $5 \mathrm{a}$ and $\mathrm{b})$. The other changes observed were interstitial edema and the appearance of vacuoles in ISO alone treated rats. RTSM treatment mitigated ISO-induced inflammatory changes in cardiac tissues, indicating that RTSM efficiently cured the tissue lesions in a dosedependent manner (Fig. 5c and d).

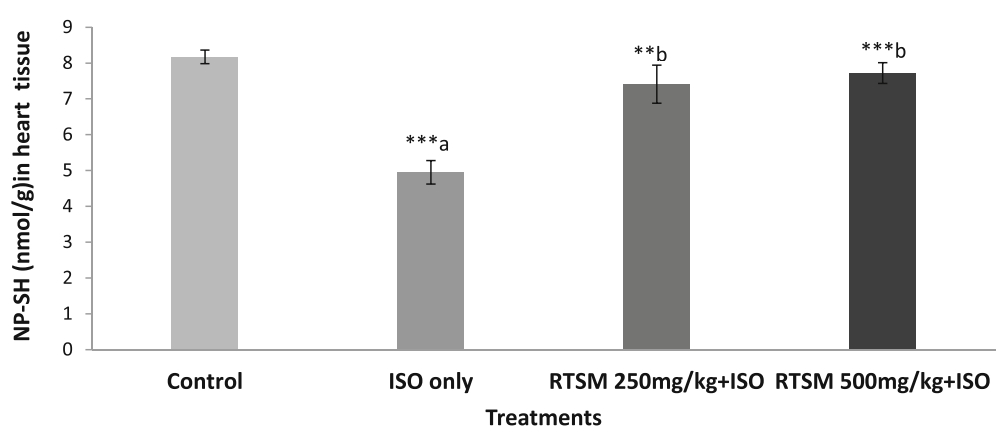

Fig. 2 Effect of RTSM on the level of NP-SH (Nonprotein sulphydryl) in the heart tissue of the rats treated with Isoproteronol. All value represent mean \pm SEM ${ }^{* *} P<0.01$, ${ }^{* *} p<0.001$; ANOVA, followed by Dunnett's multiple comparison test. ${ }^{a}$ As compared with control group. ${ }^{b}$ As compared with only ISO only groups 


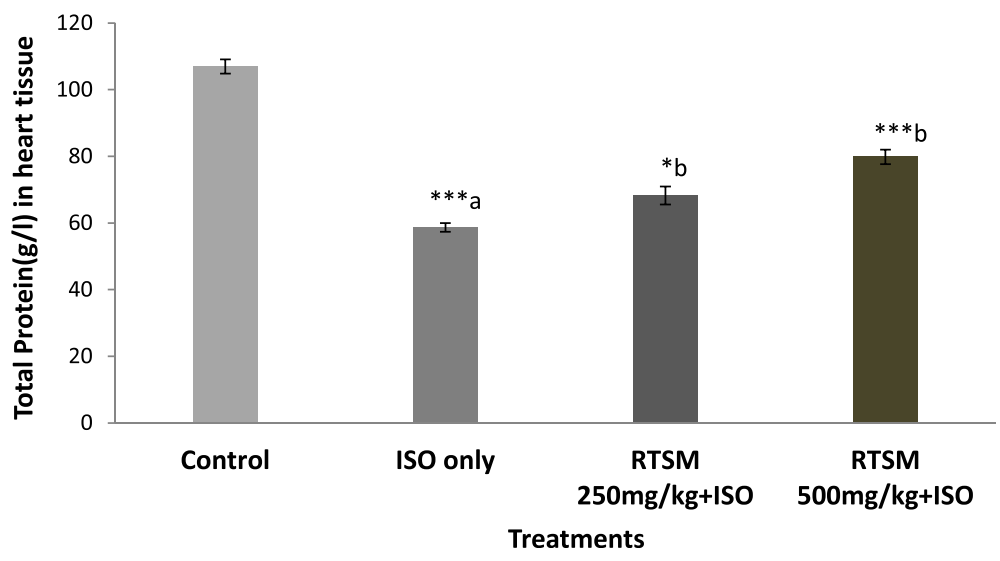

Fig. 3 Effect of RTSM on the level of TP (Total Protein) in the heart tissue of the rats treated with Isoproteronol. All value represent mean \pm SEM ${ }^{*} P<0.05,{ }^{* *} p<0.001$; ANOVA, followed by Dunnett's multiple comparison test. ${ }^{\mathrm{a}}$ As compared with control group. ${ }^{\text {b } A s ~ c o m p a r e d ~ w i t h ~ o n l y ~ I S O ~}$ only groups

\section{Discussion}

Based on co-TLC, ${ }^{1} \mathrm{H}$ and ${ }^{13} \mathrm{C}-\mathrm{NMR}$ and compared directly with published data, compounds $1,2,3,4$ and 5 were isolated and identified before as gallocatechin $\mathbf{1}$, taxifolin 2, myricetin-3-O- $\beta$-glucoside 3 , catechin 4 and epicatechin 5 , respectively $[6,38,39]$. Compounds 6 was identified as $3^{\prime}, 8$-binaringenin. The reported structure was confirmed by comparison with previously reported spectral data $[39,40]$. Compound 6 was isolated for the first time from this species.

The present study reveals a, hitherto unknown, cardioprotective pharmacological effect of RTSM in an animal model of ISO-induced cardiotoxicity. Moreover, we show that oxidative stress that underpins ISO-induced cardiac injury serves as a prime target of RTSM in ameliorating pathological changes associated with ISO administration. Along those lines, RTSM significantly down regulated serum enzymes indicative of cardiac injury and significantly thwarted ISO-associated alterations in serum lipid profiles. Furthermore, RTSM treatment robustly mitigated ISO-induced alterations in cardiac tissue redox balance.

Mechanistically, the outcome of ISO treatment in rats comprises a myriad of biochemical alterations in the cardiac tissue [41]. ISO-elicited histopathological modifications

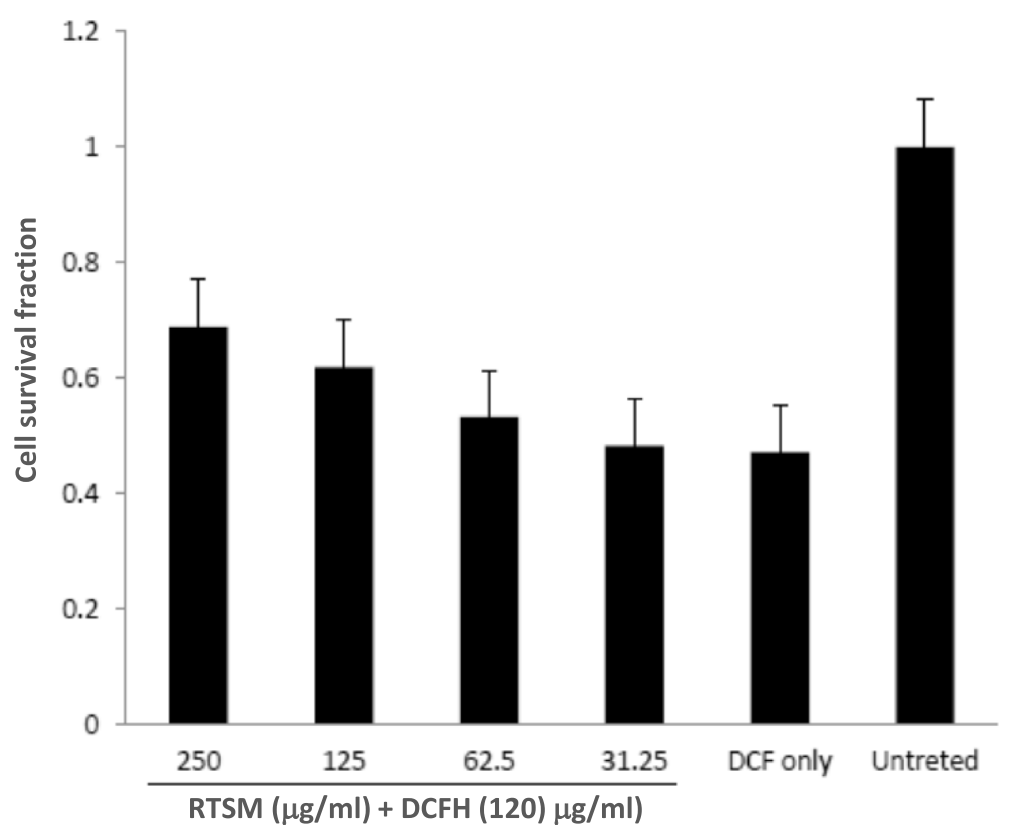

Fig. 4 Cardioprotective effect of RTSM against DCFH-induced cytoxicity on cultured cardiomyoblast cells (H9C2) at $48 \mathrm{~h}$ post-treatment 


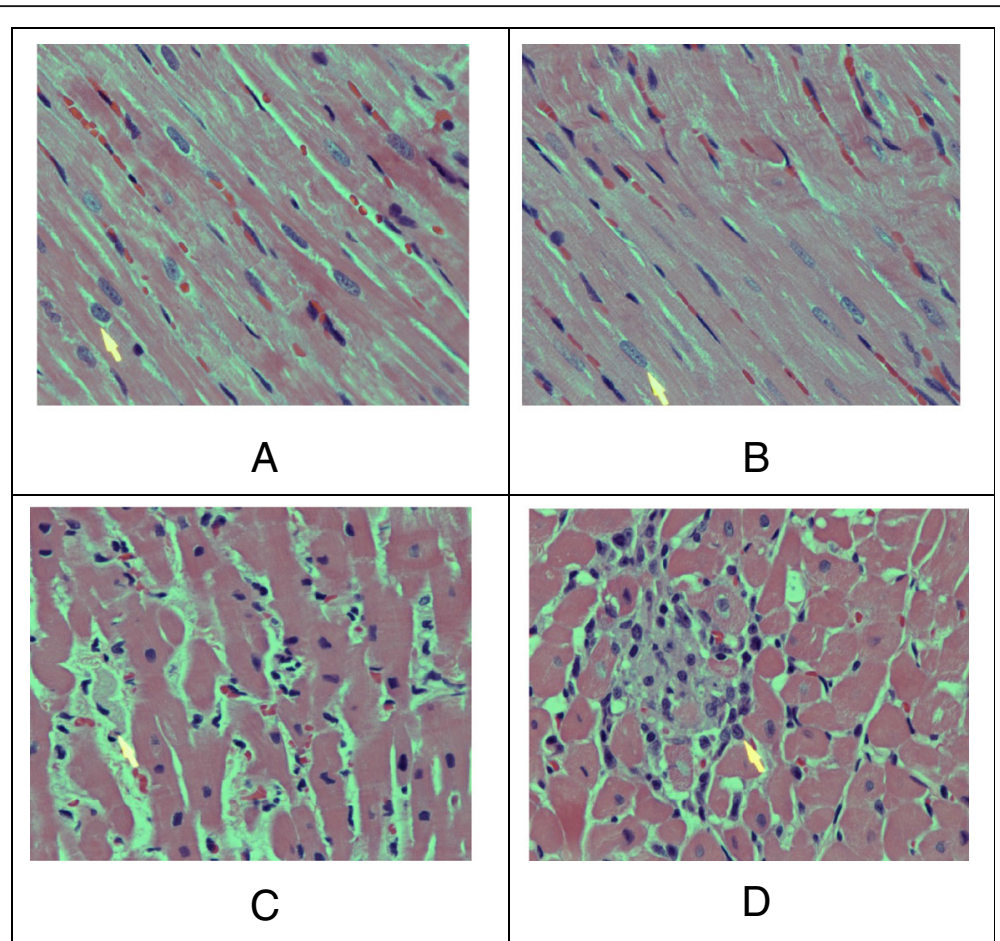

Fig. 5 Photomicrography of cardiac tissue of rats showing the effect of RTSM. a Normal (control group) showing no significant pathology. H.\& E. 400x; b Cardiac tissue showing myocardial necrosis with lymphohistiocytic, reaction around the necrotic myocardial fibers in rats myocardial cells treated with ISO only. H. \& E. 600x; c RTSM (250 mg/kg) plus ISO pretreatment showing slightly disorganized myocardial fibres with focal chronic inflammation. H. \& E. 600x. d RTSM (500 mg/kg) plus ISO pretreated group showing a small focus of myocardial fibres tic reaction. H. \& E. 600x

are paralleled by oxidative and nitrosative stress resulting in the modification of redox enzymes such as superoxide dismutase, catalase and glutathione [42] as well as endogenous redox-sensitive mediators such as nitric oxide [43] and hydrogen sulfide. ISO-triggered generation of reactive oxygen species in cardiac tissue fosters enhanced apoptosis of cardiac cells [44] and is associated with increased cytosolic calcium, cAMP and mitochondrial depolarization [45]. Strikingly, these changes also involve endoplasmic reticulum stress in cardiac cells [46]. Ramifications of ISO treatment further include modulation of various signaling cascades including the activation of NF-kB [47] and mitogen-activated protein kinases [48]. It is tempting to speculate that these mechanisms participate in the amelioration of oxidative stress and cardioprotectivity conferred by RTSM treatment.

The antioxidant and cardiovascular beneficial effects of RTSM may be attributed to its bioactive phytochemical constituents. Rhus tripartita fruits were recently shown to contain a wide array of phytochemicals but were remarkably rich in flavones and betulinic acid [49]. Interestingly, flavones were previously reported to ameliorate ISO-induced cardiac injury [50] and hyperlipidemia [51]. Intriguingly, flavones were previously shown to alleviate ISO-induced increase in MDA levels [52]. Accordingly, our data show that RTSM attenuated ISO- induced increased MDA levels in cardiac tissue. DCFH is generally used to measure in vitro oxidative stress generated by free radicals through the principle of oxidation of DCFH to the fluorescent DCF [53]. In this study, we used DCFH because of its high toxicity on cultured cells. Our in vitro data showing cardioprotection against DCFH-induced injury was in line with the in vivo effects of RTSM in isoproteronol-myocardiac tissue damage in rats. Taken together, these results confirmed the cardioprotective potential of RTSM by using two different toxins in two different experimental models.

\section{Conclusion}

In summary, sex compounds were isolated and identified. Compound 3',8-binaringenin (6) was isolated for the first time from the stem part of Rhus tripartita RTSM treatment ameliorates experimental cardiac injury in rats effective, at least in part, by its antioxidant properties. Our study, thus, provides biological evidence for the cardiovascular beneficial effects of Rhus tripartita used in Arabian traditional medicine.

\section{Acknowledgment}

The authors extend their appreciation to the Deanship of Scientific Research at King Saud University for funding this work through research group no. RGP-262. 


\section{Funding}

The research work was supported by Deanship of Scientific Research at King Saud University through research group no. RGP-262.

\section{Availability of data and materials}

All data generated or analyzed during this study are included in this published article.

\section{Authors' contributions}

AAS, MSA and MSAL-D designed the experiments SR, MOA, MSA, VE and MKP wrote the manuscript, AAS, MSA and LP supervised the work; all the authors read and approved the final manuscript.

\section{Competing interests}

The authors declare that they have no competing interests.

\section{Consent for publication}

Not applicable. The manuscript does not include details, images, or videos relating to individual participants.

\section{Ethics approval and consent to participate}

The present study was approved by the Research Ethics Committee of the College of Pharmacy, King Saud University (Riyadh, Saudi Arabia). The handling of animals was in compliance with the Guidelines for the Care and Use of Laboratory Animals by the Animal Care Center.

\section{Author details}

${ }^{1}$ Pharmacognosy Department (Medicinal Aromatic \& Poisonous Plants Research Centre), College of Pharmacy, King Saud University, P.O. Box 2457, Riyadh 11451, Saudi Arabia. ${ }^{2}$ Phytochemistry Department, National Research Centre, 33 El Bohouth St. (former El Tahrir st.) 12622, Dokki, Giza, Egypt. ${ }^{3}$ Pathology Department, KKUH, King Saud University, Po.box 2925, Riyadh 11461, Saudi Arabia. ${ }^{4}$ Natural Products \& Food Research and Analysis (NatuRA), Department of Pharmaceutical Sciences, University of Antwerp, Universiteitsplein 1, 2610 Antwerp, Belgium.

\section{Received: 27 January 2016 Accepted: 24 August 2016}

\section{Published online: 08 September 2016}

\section{References}

1. Buch MH, Prendergast BD, Storey RF. Antiplatelet therapy and vascular disease: an update. Ther Adv Cardiovasc Dis. 2010;4:249-75

2. Bi F-J, Zhang H, Xu Y-J, Hu J. Protective effect of catalpol on isoproterenolinduced myocardial injury in Wistar rats. Afr J Biotechnol. 2012;11:9270-5.

3. Al-Yahya MA, Mothana RA, Al-Said MS, El-Tahir KE, Al-Sohaibani M, Rafatullah S. Citrus medica "Otroj": attenuates oxidative stress and cardiac dysrhythmia in isoproterenol-induced cardiomyopathy in rats. Nutrients. 2013;5(11):4269-83.

4. Abdel-Azim NS, Shams KA, Shahat AA, El Missiry MM, Ismail SI, Hammouda FM. Egyptian herbal drug industry: Challenges and future prospects. Res J Med Plant. 2011;5:136-44.

5. Murphy KJ, Chronopoulos AK, Singh I, Francis MA, Moriarty H, Pike MJ, et al. Dietary flavanols and procyanidin oligomers from cocoa (Theobroma cacao) inhibit platelet function. Am J Clin Nutr. 2003;77(6):1466-73.

6. Caballero-George C, Vanderheyden PM, De Bruyne T, Shahat AA, Van den HeuveH, Solis PN, Gupta MP, Claeys M, Pieters L, Vauquelin G, Vlietinck AJ. In Vitro Inhibition of [3H]-Angiotensin II Binding on the Human AT1 Receptor by Proanthocyanidins from Guazuma ulmifolia Bark. Planta Medica. 2002;68(12):1066-71

7. Kossah R, Nsabimana C, Zhao J, Chen H, Tian F, Zhang H, Chen W. Comparative Study on the Chemical Composition of Syrian Sumac (Rhus coriaria L.) and Chinese Sumac (Rhus typhina L.) Fruits. Pak J Nutr. 2009;8(10):1570-4.

8. Mossa JS, Rafatullah S, Galal AM, AI-Yahya MA. Pharmacological Studies of Rhus retinorrhaea. Pharm Biol. 1995;33(3):242-6.

9. El-Mokasabi F. The State of the Art of Traditional Herbal Medicine in the Eastern Mediterranean Coastal Region of Libya. Middle-East J Sci Res. 2014;21(4):575-82.

10. Itidel C, Chokri M, Mohamed B, Yosr Z. Antioxidant activity, total phenolic and flavonoid content variation among Tunisian natural populations of
Rhus tripartita (Ucria) Grande and Rhus pentaphylla Desf. Ind Crop Prod. 2013;51:171-7.

11. Mahjoub MA, Ammar S, Edziri H, Mighri N, Bouraoui A, Mighri Z. Antiinflammatory and antioxidant activities of some extracts and pure natural products isolated from Rhus tripartitum (Ucria). Med Chem Res. 2010;19(3):271-82.

12. Abbassi F, Hani K. In vitro antibacterial and antifungal activities of Rhus tripartitum used as antidiarrhoeal in Tunisian folk medicine. Nat Prod Res. 2012;26(23):2215-8.

13. Amin A, Mousa M. Merits of anti-cancer plants from the Arabian Gulf region. Cancer Ther. 2007:5:55-66

14. Wang Y, Chan FL, Chen S, Leung LK. The plant polyphenol butein inhibits testosterone-induced proliferation in breast cancer cells expressing aromatase. Life Sci. 2005;77(1):39-51.

15. Zargham H, Zargham R. Tannin extracted from Sumac inhibits vascular smooth muscle cell migration. McGill J Med. 2008;11(2):119.

16. Shahat AA, Ahmed HH, Hassan RA, Hussein AA. Antioxidant activity of proanthocyanidins from Adansonia digitata fruit. Asian Pac J Trop Med. 2008;1(3):55-59.

17. Shahat AA, Ismail SI, Hammouda FM, Azzam SA, Lemiere G, De Swaef S, De Bruyne T, Pieters L, Vlietinck AJ. Anti-HIV activity of Flavonoids and Proanthocyanidins from Crataegus sinaica. Phytomedicine. 1998;5(2):133-6.

18. Shahat AA, Cos P, De Bruyne T, Apers S, Hammouda FM, Ismail S, Azzam S, Cleays M, Goovaerts E, Pieters L, Vanden Berghe D, Vlietinck AJ. Antiviral and antioxidant activity of flavonoids and proanthocyanidins from Crateagus Sinaica Boiss. Planta Med. 2002;68:539-41.

19. Al-Yahya M, Raish M, AlSaid MS, Ahmad A, Mothana RA, Al-Sohaibani M, Al-Jenoobi Fl, Al-Dosari MS, Parvez MK and Rafatullah S. 'Ajwa' dates (P. dactylifera L.) extracts ameliorates isoproterenol-induced cardiomyopathy through downregulation of oxidative, inflammatory and apoptotic molecules in rodent model. Phytomedicine. 2016;23:1240-8

20. Assmann G. A fully enzymatic colorimetric determination of HDL-cholesterol in the serum. Internist. 1970;20:559.

21. Ojha SK, Goyal S, et al. Pyruvate attenuates cardiac dysfunction and oxidative stress in isoproterenol-induced cardiotoxicity. Exp Toxicol Pathol. 2012;64:393-9.

22. Rona $\mathrm{G}$, Chapel $\mathrm{Cl}$, et al. An infarct-like myocardial lesion and other toxic manifestations produced by isoproterenol in the rat. AMA Arch Pathol. 1959;67:4543-455.

23. Bergmeye HU. Method of Enzymatic Analysis. London, UK: Academic; 1974.

24. Okinada S, Kumagai H, Ebashi S, Sugita H, Momoi H, Toyokura Y. Serum creatininephosphokinase. Activity in progressive muscular dystrophy and neuromuscular disease. Arch Nurol. 1961:4:520-5.

25. Demacher PNM, Hijamaus AGM. A study of the use of polyethylene glycol in estimatingcholesterol. Clin Chem. 1980;26:1775-8.

26. Foster LB, Dunn RT. Stable reagents for the determination of serum triglycerides by acolorimetric Hantzch condensation method. Clin Chem. 1973;19:338-40.

27. Burstein M, Scholnick HR. Lipoprotein-polyanion-metal interaction. Adv Lipid Res. 1973;11:67-108.

28. Utley HC, Bernheim F, Hochslein P. Effect of sulfhydryl reagent on peroxidation inmicrosome. Arch Biochem Biophys. 1967;260:521-31.

29. Sedlak J, Lindsay RH. Estimation of total, protein bound and non-protein SH groups in tissuewith Ellman's reagent. Anal Biochem. 1968;25:192-205.

30. Culling CFA. Handbook of Histopathological and Histochemical Techniques. 3rd ed. London, UK: Butterworth and Co; 1974. p. 73-159.

31. Derbali A, Mnafgui K, Affes M, Derbali F, Hajji R, Gharsallah N, et al. Cardioprotective effect of linseed oil against isoproterenol-induced myocardial infarction in Wistar rats: a biochemical and electrocardiographic study. J Physiol Biochem. 2015;71(2):281-8.

32. Joukar S, Bashiri H, Dabiri S, Ghotbi P, Sarveazad A, Divsalar K, et al. Cardiovascular effects of black tea and nicotine alone or in combination against experimental induced heart injury. J Physiol Biochem. 2012;68(2):271-9.

33. Salimeh A, Mohammadi M, Rashidi B. Preconditioning with diosgenin and treadmill exercise preserves the cardiac toxicity of isoproterenol in rats. J Physiol Biochem. 2013;69(2):255-65.

34. El-Tantawy WH. Biochemical effects of Solidago virgaurea extract on experimental cardiotoxicity. J Physiol Biochem. 2014;70(1):33-42.

35. Balta N, Stoian I, Petec C, Petec G. Decreased SOD activity and increased nitrates level in rat heart with left ventricular hypertrophy induced by isoproterenol. Romanian. J Physiol. 1999;36(3-4):175-82. 
36. Rota C, Chignell CF, Mason RP. Evidence for free radical formation during the oxidation of $2^{\prime}-7^{\prime}$-dichlorofluorescin to the fluorescent dye2'-7'dichlorofluorescein by horseradishperoxidase: possible implications foroxidative stress measurements. Free Rad Biol Med. 1999;27:873-81.

37. Diaz-Munoz M, Alvarez-Perez MA, Yanez L, Vidrio S, Martinez L, Rosas $G$, et al. Correlation between oxidative stress and alteration of intracellular calcium handling in isoproterenol-induced myocardial infarction. Mol Cell Biochem. 2006;289(1-2):125-36.

38. Shahat AA, Alsaid MS, Kotob SE, Hosseiny HA, El-Gandi AAM, Ahmed HH. Biochemical and Histological Evidences for the Antitumor Potential of Teucrium oliverianum and Rhazya stricta in Chemically-induced Hepatocellular Carcinoma. Afr J Tradit Complement Altern Med. 2016;13(1):62-70.

39. Shahat AA, Hammouda FM, Ismail SI, Azzam SA, De Bruyne T, Lasure A, Van Poel B, Pieters L, Vlietinck AJ. Anti-Complementary Activity of Crataegus Sinaica. Planta Med. 1996:62(1):10-3.

40. Ghanem MTM, Radwan HMA, Mahdy E-SM, Elkholy YM, Hassanein HD, Shahat AA. Phenolic compounds from Foeniculum vulgare (Subsp: Piperitum) herb and evaluation of hepatoprotective antioxidant activity. Pharmacognosy Res. 2012;4:104-8.

41. Ahmed MS, Galal AM, Ross SA, Ferreira D, ElSohly MA, Ibrahim AS, Mossa JS, El-Feraly FS. A weakly antimalarial biflavanone from Rhus retinorrhoea. Phytochemistry. 2001;58(4):599-602.

42. Garg M, Khanna D. Exploration of pharmacological interventions to prevent isoproterenol-induced myocardial infarction in experimental models. Ther Adv Cardiovasc Dis. 2014;8(4):155-69.

43. Al Numair KS, Chandramohan G, Alsaif MA, Baskar AA. Protective effect of morin on cardiac mitochondrial function during isoproterenol-induced myocardial infarction in male Wistar rats. Redox report. Commun Free Radic Res. 2012;17(1):14-21.

44. Sartoretto JL, Kalwa H, Pluth MD, Lippard SJ, Michel T. Hydrogen peroxide differentially modulates cardiac myocyte nitric oxide synthesis. Proc Natl Acad Sci U S A. 2011;108(38):15792-7.

45. Liu L, Cui J, Yang Q, Jia C, Xiong M, Ning B, et al. Apocynin attenuates isoproterenol-induced myocardial injury and fibrogenesis. Biochem Biophys Res Commun. 2014:449(1):55-61.

46. Branco AF, Sampaio SF, Wieckowski MR, Sardao VA, Oliveira PJ. Mitochondrial disruption occurs downstream from beta-adrenergic overactivation by isoproterenol in differentiated, but not undifferentiated H9c2 cardiomyoblasts: differential activation of stress and survival pathways. Int J Biochem Cell Biol. 2013;45(11):2379-91.

47. Song S, Gao P, Xiao H, Xu Y, Si LY. Klotho suppresses cardiomyocyte apoptosis in mice with stress-induced cardiac injury via downregulation of endoplasmic reticulum stress. PLoS One. 2013;8(12):e82968.

48. Li Y, Shen D, Tang X, Li X, Wo D, Yan H, et al. Chlorogenic acid prevents isoproterenol-induced hypertrophy in neonatal rat myocytes. Toxicol Lett. 2014;226(3):257-63.

49. Zhang GX, Kimura S, Nishiyama A, Shokoji T, Rahman M, Yao L, et al. Cardiac oxidative stress in acute and chronic isoproterenol-infused rats. Cardiovasc Res. 2005;65(1):230-8.

50. Tlili N, Mejri H, Yahia Y, Saadaoui E, Rejeb S, Khaldi A, et al. Phytochemicals and antioxidant activities of Rhus tripartitum (Ucria) fruits depending on locality and different stages of maturity. Food Chem. 2014;160:98-103.

51. Lu CC, Xu YQ, Wu JC, Hang PZ, Wang Y, Wang C, et al. Vitexin protects against cardiac hypertrophy via inhibiting calcineurin and CaMKIl signaling pathways. Naunyn Schmiedeberg's Arch Pharmacol. 2013;386(8):747-55.

52. Queenthy SS, John B. Diosmin exhibits anti-hyperlipidemic effects in isoproterenol induced myocardial infarcted rats. Eur J Pharmacol. 2013;718(1-3):213-8.

53. Cheng $D$, Zhu $C$, Cao J, Jiang $W$. The protective effects of polyphenols from jujube peel (Ziziphus Jujube Mill) on isoproterenol-induced myocardial ischemia and aluminum-induced oxidative damage in rats. Food Chem Toxicol. 2012;50(5):1302-8.

\section{Submit your next manuscript to BioMed Central and we will help you at every step:}

- We accept pre-submission inquiries

- Our selector tool helps you to find the most relevant journal

- We provide round the clock customer support

- Convenient online submission

- Thorough peer review

- Inclusion in PubMed and all major indexing services

- Maximum visibility for your research

Submit your manuscript at www.biomedcentral.com/submit
) Biomed Central 